\title{
Global distribution of cyanobacterial ecotypes in the cold biosphere
}

\author{
Anne D Jungblut ${ }^{1}$, Connie Lovejoy ${ }^{2}$ and Warwick F Vincent ${ }^{1}$ \\ ${ }^{1}$ Département de Biologie and Centre d'Etudes Nordiques, Université Laval, Quebec City, Quebec, Canada \\ and ${ }^{2}$ Québec-Océan, Département de Biologie, and Institut de biologie intégrative et des systèmes (IBIS), \\ Université Laval, Quebec City, Quebec, Canada
}

\begin{abstract}
Perennially cold habitats are diminishing as a result of climate change; however, little is known of the diversity or biogeography of microbes that thrive in such environments. Here we use targeted 16S rRNA gene surveys to evaluate the global affinities of cold-dwelling cyanobacteria from lake, stream and ice communities living at the northern limit of High Arctic Canada. Pigment signature analysis by HPLC confirmed the dominance of cyanobacteria in the phototrophic communities of these High Arctic microbial mats, with associated populations of chlorophytes and chromophytes. Microscopic analysis of the cyanobacteria revealed a diverse assemblage of morphospecies grouping into orders Oscillatoriales, Nostocales and Chroococcales. The 16S rRNA gene sequences from six clone libraries grouped into a total of 24 ribotypes, with a diversity in each mat ranging from five ribotypes in ice-based communities to 14 in land-based pond communities. However, no significant differences in composition were observed between these two microbial mat systems. Based on clone-library and phylogenetic analysis, several of the High Arctic ribotypes were found to be $>99 \%$ similar to Antarctic and alpine sequences, including to taxa previously considered endemic to Antarctica. Among the latter, one High Arctic sequence was found $99.8 \%$ similar to Leptolyngbya antarctica sequenced from the Larsemann Hills, Antarctica. More than $68 \%$ of all identified ribotypes at each site matched only cyanobacterial sequences from perennially cold terrestrial ecosystems, and were $<97.5 \%$ similar to sequences from warmer environments. These results imply the global distribution of low-temperature cyanobacterial ecotypes throughout the cold terrestrial biosphere.
\end{abstract}

The ISME Journal (2010) 4, 191-202; doi:10.1038/ismej.2009.113; published online 5 November 2009

Subject Category: microbial population and community ecology

Keywords: 16S rRNA gene; biogeography; cyanobacteria; dispersal; microbial mats; polar

\section{Introduction}

Recently attention has been focused on how the Earth's atmosphere has rapidly warmed over the last decade; however, vast regions of the planet remain at temperatures near or below freezing. Extreme cold is a defining feature of High Arctic, Antarctic and high alpine sites, which are separated by large distances and climatic barriers. The ecology of these cryoenvironments is mostly microbial, and existence of a perennially cold terrestrial biosphere has implications for microbial speciation, dispersal, biogeography and gene exchange at a planetary scale. Globally dispersed microbial ecotypes have

Correspondence: AD Jungblut, Département de Biologie and Centre d'Études Nordiques, Université Laval, Quebec City, Quebec, Canada G1V 0A6.

E-mail: anne-dorothee-jungblut.1@ulaval.ca

Received 9 July 2009; revised 28 September 2009; accepted 28

September 2009; published online 5 November 2009 been described from hot springs and other geothermal environments (Papke et al., 2003; Bhaya et al., 2007; Ward et al., 2008), but microbiota at the opposite thermal extreme, cold-dwelling taxa, have received little attention.

Cyanobacteria are common throughout the terrestrial North and South Polar Regions, where they form benthic mats and films at the bottom of lakes, ponds and streams (Zakhia et al., 2007). These communities often dominate total ecosystem biomass and productivity, and must contend with persistent low temperatures, repeated freeze-thaw cycles and highly variable light, nutrient and osmotic regimes (Vincent, 2000). Filamentous, mucilage-producing Oscillatoriales are responsible for much of the biomass and three-dimensional structure of these polar mat consortia. They have been shown to tolerate a wide range of conditions and to maintain slow net growth despite the frigid ambient temperatures (Tang et al., 1997). 
Previous work on polar cyanobacteria using both morphological and molecular methods in the Polar Regions, has mostly been performed in the Antarctic, where cosmopolitan and endemic taxa are reported (Komárek, 1999; Taton et al., 2003, 2006a,b; Jungblut et al., 2005; Comte et al., 2007). By comparison, little is known about Arctic cyanobacteria, which although inhabiting a similar environment, are potentially more connected to temperate latitudes than Antarctica cyanobacteria, which are isolated by the Southern Ocean.

In the present study we evaluated the global distribution of cyanobacteria by comparing communities from the most northern reaches of North America (High Arctic Canada) with those from analogous sites in Antarctica. We determined the diversity and community structure of cyanobacterial mats collected from lakes, ponds and streams on land, and from meltwater lakes on ice shelves, at the northern limit of the North American Arctic, specifically Ward Hunt Island (latitude $83.1^{\circ} \mathrm{N}$ ) and its vicinity in Quttinirpaaq ('top of the world' in Inuktitut) National Park, Nunavut, Canada. Cyanobacterial diversity was determined in the microbial mats by way of morphological characters, 16S rRNA gene similarity and pigment biomarkers.

\section{Materials and methods}

\section{Study sites}

The samples from Ellesmere Island in Quttinirpaaq National Park (Supplementary Figure S1), Canadian High Arctic, were taken between 8 and 15 July 2007 from the following sites: Ward Hunt Lake (WH-Lake) $83^{\circ} \mathrm{N}$ 05.289, $74^{\circ} \mathrm{W}$ 10.048; Quttinirpaaq Lagoon (QLagoon) $83^{\circ} \mathrm{N}$ 05.843, $74^{\circ} \mathrm{W}$ 15.018; Markham Ice Shelf (MIS) $83^{\circ} \mathrm{N} 01.898,71^{\circ} \mathrm{W}$ 30.812; Ward Hunt Ice Shelf (WIS) $83^{\circ} \mathrm{N} 04.949,74^{\circ} \mathrm{W}$ 26.281; Antoniades Pond (Pond-A) $82^{\circ} \mathrm{N}$ 58.957, $75^{\circ} \mathrm{W} 24.161$ and the inflow from Lake B into Lake A (Inflow-A) $82^{\circ} \mathrm{N} 58.801,75^{\circ} \mathrm{W}$ 25.372. All environmental measurements and samples were from 10- to 20-cm water depths. WH-Lake has a maximum depth of $5.5 \mathrm{~m}$ and a total area of $0.37 \mathrm{~km}^{2}$, and is the most northern lake of North America (Villeneuve et al., 2001). The ice-free littoral zones were completely covered by cohesive microbial mats. Q-Lagoon is located between the northern coastline of Ward Hunt Island and an ice rise (thick ice on land). It has an area of $3 \mathrm{~km}^{2}$, with meltwater inflows from the island and the ice rise. The shallow inshore region of the lagoon along Ward Hunt Island was covered with thick accumulation of microbial mat flakes. WIS $\left(400 \mathrm{~km}^{2}\right)$ is a floating mass of landfast ice approximately $40 \mathrm{~m}$ thick, with a ridge and trough morphology. The troughs were filled with meltwater ponds up to $15 \mathrm{~km}$ long, approximately $3 \mathrm{~m}$ deep and $10-20 \mathrm{~m}$ wide, with localized accumulations of sediments and loose aggregates of microbial mats ('matlets'; Mueller and Vincent, 2006). In July 2007, MIS had an area of $50 \mathrm{~km}^{2}$ and a third of its surface was covered with sediment. Mat-containing sediments occurred on raised mounds of the ice and in meltwater ponds in the form of microbial matlets (Mueller et al., 2006). Inflow A was approximately $10 \mathrm{~m}$ wide and $30 \mathrm{~cm}$ deep, and its submerged berm was coated with mucilaginous benthic microbial mats. Pond-A, with an area of approximately $300 \mathrm{~m}^{2}$, contained thick mucilaginous orange pigmented microbial mats that covered the littoral zone.

\section{Sampling and water analysis}

Two or more samples were obtained from all the sites, except for Pond-A and Inflow-A where only single samples were taken. For the ice shelf sites, adjacent meltwater ponds were considered replicates and replicates for the lakes were from sites up to several hundred meters apart along the shorelines. After collection the samples were divided into subsamples for pigment, DNA and morphological analysis. Mat material for DNA and pigments was stored at $-80^{\circ} \mathrm{C}$ and the subsamples for morphological characterization were kept in the dark at $4{ }^{\circ} \mathrm{C}$ until examination by microscopy.

Water temperature, $\mathrm{pH}$ and conductivity were determined at each site using a portable instrument (pH/Con 10 Series; Oakton Instruments, Vernon Hills, IL, USA). Water samples for nutrient analysis were collected from just above the microbial mats, in acid-washed bottles, and stored at $4{ }^{\circ} \mathrm{C}$ until analysis. Total nitrogen and total phosphorus were determined by standard methods (Strainton et al., 1977; QuikChem 10-107-06-2-K) at Institut National de la Recherche Scientifique (Quebec City, QC, Canada).

\section{Microscopic characterization}

Cyanobacteria in the mats were examined at $\times 1000$ magnification using an Olympus inverted light microscope (model IX71) equipped with DIC and phase contrast. Images were taken and measurements were taken using an ocular micrometer. Separation of taxa was based on morphological descriptions (Geitler, 1932; Anagnostidis and Komárek, 1988, 1990; Komárek and Anagnostidis, 1989, 1998; Villeneuve et al., 2001; Taton et al., 2008).

\section{Pigment analysis}

Total pigments from subsamples were extracted in the dark by grinding the frozen material for $2 \mathrm{~min}$ followed by sonication $(3 \times 20 \mathrm{~s}$ at $20 \mathrm{~W})$ in 4 or $6 \mathrm{ml}$ $90 \%$ acetone:water (vol/vol) mixture, and left overnight at $-20^{\circ} \mathrm{C}$ under an argon gas atmosphere. The extracts were recovered following centrifugation at 4150 r.p.m. for $15 \mathrm{~min}$ at $4{ }^{\circ} \mathrm{C}$. The supernatant was then filtered through a $0.2 \mu \mathrm{m}$ pore size PTFE Acrodisc filter (Pall Corporation, Ann Arbor, MI, USA) and stored in the dark at $-70^{\circ} \mathrm{C}$ under an argon atmosphere until high-performance liquid chromatography (HPLC) analysis. This extraction procedure was repeated for the residual material 
until no further coloration was detected in the extract solution. HPLC analysis was performed on $50 \mu \mathrm{l}$ of injected sample using a ProStar HPLC system (Varian, Palo Alto, CA, USA) equipped with a Symmetry C8 column $(3.5 \mu \mathrm{m}$ pore size, $4.6 \times$ $150 \mathrm{~mm}$; Waters Corporation, Milford, MA, USA) at $25^{\circ} \mathrm{C}$ with a C8 guard column $(5 \mu \mathrm{m}$ pore size, $3.9 \times 20 \mathrm{~mm}$; Waters Corporation). The HPLC peaks were detected by diode-array spectroscopy (350$750 \mathrm{~nm})$. Absorbance chromatograms at $384 \mathrm{~nm}$ (for scytonemin), $440 \mathrm{~nm}$ (for chlorophylls) and $450 \mathrm{~nm}$ (for carotenoids) were recorded. Chlorophylls were also detected by fluorescence (excitation, $40 \mathrm{~nm}$; emission, $650 \mathrm{~nm}$ ). The HPLC solvent protocol was based on gradient dilution with two solvent mixtures (Zapata et al., 2000). The flow rate was $1 \mathrm{ml} \mathrm{min}^{-1}$, with an equilibrium time of $5 \mathrm{~min}$. Standards (chlorophyll (chl.)- $a, b$ and $c_{2} ; \beta, \beta$ carotene, canthaxanthin, diadinoxanthin, echinenone, fucoxanthin, lutein, myxoxanthophyll and zeaxanthin) were obtained for identification and quantification of detected pigments (Sigma Inc., St Louis, MO, USA; DHI Water \& Environments, Hørsholm, Denmark; Bonilla et al., 2005). Other carotenoids were quantified based on the published extinction coefficients of related pigments: HFUlike, $\quad 142 \mathrm{lg}^{-1} \mathrm{~cm}^{-1}$; uriolide-like, $166 \mathrm{lg}^{-1} \mathrm{~cm}^{-1}$; 19'-hexanoylofucoxanthin-like, $142 \mathrm{~g} \mathrm{~g}^{-1} \mathrm{~cm}^{-1}$; peridinin-like, $136 \mathrm{lg}^{-1} \mathrm{~cm}^{-1}$; astaxanthin, $210 \mathrm{lg}^{-1} \mathrm{~cm}^{-1}$; antheraxanthin-like, $244 \mathrm{lg}^{-1} \mathrm{~cm}^{-1}$; diatoxanthin, $210 \mathrm{lg}^{-1} \mathrm{~cm}^{-1}$ and monadoxanthin-like, $250 \mathrm{lg}^{-1} \mathrm{~cm}^{-1}$. The extinction coefficient of $\beta, \beta$-carotene $\left(250 \mathrm{lg}^{-1} \mathrm{~cm}^{-1}\right)$ was used for unknown carotenoids (Jeffrey et al., 1997) and scytonemin was quantified as described by GarciaPichel et al. (1992).

\section{DNA extraction}

On return from the field, the mat material for DNA analysis was freeze-dried and suspended in $800 \mu \mathrm{l} \mathrm{XS}$ buffer (1\% potassium-methyl-xanthogenate; $800 \mathrm{mM}$ ammonium acetate; $20 \mathrm{mM}$ EDTA; $1 \%$ sodium dodel sulfate; $100 \mathrm{~mm}$ Tris-HCl (pH 7.4); Tillett and Neilan, 2000). The mixture was vortex-mixed and incubated at $65^{\circ} \mathrm{C}$ for $4 \mathrm{~h}$. The extracts were cooled overnight at $-20{ }^{\circ} \mathrm{C}$ and cell debris were removed by centrifugation at $12000 \mathrm{~g}$ for $10 \mathrm{~min}$. An equal volume of phenolchloroform-isoamyl alcohol (25:24:1) was then added to the removed aqueous phase and centrifuged at $3000 \mathrm{~g}$ for $3 \mathrm{~min}$. The two steps were repeated twice. DNA was precipitated overnight by addition of 1 volume of isopropanol and $1 / 10$ volume of $4 \mathrm{M}$ ammonium acetate at $-20^{\circ} \mathrm{C}$. The precipitated DNA was pelleted by centrifugation at $12000 \mathrm{~g}$ for $10 \mathrm{~min}$ and washed with $70 \%$ ethanol. The extracted DNA was then resuspended in $100 \mu$ l of sterile water.

\section{PCR}

All PCR reactions were performed using Advantage 2 PCR kits with proof-reading ability, in a $20 \mu \mathrm{l}$ reaction mix using $10 \times$ Advantage 2 SA PCR buffer and $0.2 \mathrm{mM}$ dNTPs (Fermentas, Foster City, CA, USA), according to the manufacturer (Clontech, Mountain View, CA, USA). PCR amplification of cyanobacterial $16 \mathrm{~S}$ rDNA was performed using $0.5 \mu \mathrm{M}$ of each cyanobacteria-specific primer $27 \mathrm{~F} 1$ (5'-AGAGTTTGATCCTGGCTCAG-3') and 809R (5'-G CTTCGGCACGGCTCGGGTCGATA-3'). As described by Jungblut et al. (2005), these primers provide broad coverage of cyanobacterial taxa.

Cloning, RFLP analysis and sequencing

Prior to cloning, the amplified PCR products were verified by gel electrophoresis and amplicons of the target size were purified with the Qiaquick PCR Purification kit (Qiagen, Mississauga, CA, USA). PCR products were cloned using the TOPO TA cloning kit (Invitrogen, Carlsbad, CA, USA). Ligation and transformation were performed according to the manufacturer's protocols. Positive clones were transferred to 96-well plates containing Luria Bertani medium with $7 \%$ glycerol. The inserted $16 \mathrm{~S}$ rRNA sequences were amplified using vector-specific primers M13f and M13r, and subjected to restriction-fragment length polymorphism (RFLP) screening. Amplicons $(4 \mu \mathrm{l})$ were digested (overnight in separate incubations with $5 \mathrm{U}$ of restriction enzymes AluI and HpaII; Fermentas, Hanover, NH, USA) in a final reaction volume of $10 \mu \mathrm{l}$ with the appropriate buffer at $37^{\circ} \mathrm{C}$. The resulting digests were run on $2.5 \%$, low-melting point agarose gel and the generated RFLP patterns were visualized using the Bio-Rad Laboratories Gel Doc imaging system and Quantity One software (Bio-Rad Laboratories, Hercules, CA, USA, version 4.5.1). At least two clones for each unique RFLP pattern were sequenced using the vector-specific T7 universal primer (single read) at the Centre Hospitalier de l'Université Laval (CHUL, QC, Canada), using an ABI 3730xl system (Applied Biosystems, Foster City, CA, USA), which included a purification step.

\section{Total-mat-community RFLP}

Communities were compared using direct RFLP analysis of PCR products from total genomic DNA using the same restriction enzymes as above. Five units of AluI and HpaII (Fermentas) were added to $6 \mu \mathrm{l}$ of PCR product for a final volume of $10 \mu \mathrm{l}$. The generated RFLP patterns were run on $2.5 \%$, lowmelting point agarose gel and analyzed as described above. The RFLP community patterns were compared using Restdist and Neighbor in PHYLIP version 3.67 (Felsenstein, 1989).

\section{Phylogenetic analysis and diversity calculations}

All sequences were checked for chimeras using the Chimera check program at Ribosomal Data Project II (Maidak et al., 2001) and they were excluded from 
further analysis. Sequences were edited and trimmed using 4Peaks (version 1.7). The approximately 750-nt sequences were aligned using ClustalX (version 1.8; Thompson et al., 1994) and were checked manually using BBEdit Lite (version 6.1). Reference sequences were from GenBank and for each phylotype the closest match based on a BLAST search (Altschul et al., 1990) of GenBank was selected as a reference sequence. If the closest match was an uncultured clone, we also included the closest isolated strain. For comparisons, we also searched for environmental 16S rDNA sequence data from other Arctic and Antarctic sites (Priscu et al., 1998; Nadeau et al., 2001; Taton et al., 2003, 2006a, b; Jungblut et al., 2005).

The genetic differences between the cyanobacterial communities from the clone-libraries were calculated using Unifrac (Lozupone et al., 2006). Each pair of environments was compared with a weighted Unifrac matrix that takes abundances of different sequences into account using Unifrac Significance test.

Phylogenetic trees were constructed using neighbor-joining with the Kimura-2-Parameter distance matrix (DNAdist, Neighbor) and maximum-likelihood (DNAml) was computed with PHYLIP (version $3.67,19)$. Aligned partial 16S rRNA gene sequences corresponding to Escherichia coli sequence positions 129-775 were used. Confidence levels were calculated for each method by bootstrapping with 1000 and 100 reassembly events for neighbor-joining and maximum-likelihood, respectively (Seqboot, Consense). One representative for each ribotype was included in the phylogenetic analysis, and individual ribotypes or Operational Taxonomic Units (OTUs) were defined as groups of sequences, which were at least $97.5 \%$ similar (Stackebrandt and Göbel, 1994; Taton et al., 2003).

Library coverage, the Shannon-Wiener diversity index ( $\left.\mathrm{H}^{\prime}\right)$, Chao1 non-parametric richness estimates and rarefaction curves were calculated using DOTUR (Schloss and Handelsman, 2005) on a JukeCantor distance matrix. 16S rRNA gene sequences are available under GenBank accession numbers FJ977098-FJ977164 (Supplementary Table S1).

\section{Results}

Environmental properties

The six collection sites spanned a range of environmental conditions, with overlying water temperatures from $0.9^{\circ} \mathrm{C}$ in the WIS meltwater ponds to $6{ }^{\circ} \mathrm{C}$ in Pond-A (Supplementary Table S2). Pond-A had the highest $\mathrm{pH}$ among all the sites (8.28), and the lowest $\mathrm{pH}$ values were recorded in the meltwater ponds of WIS (6.45) and MIS (6.53). Highest conductivities were at the ice-based sites, with 637, 384.8 and $269.0 \mu \mathrm{S} \mathrm{cm}^{-1}$ on MIS, WIS and Q-Lagoon, respectively. Land-based sites had conductivities of $137 \mu \mathrm{S} \mathrm{cm}^{-1}$ or less. Nutrient concentrations were highest in Pond-A, with $0.961 \mathrm{mgl}^{-1}$ total nitrogen and $0.016 \mathrm{mgl}^{-1}$ total phosphorus. Total nitrogen concentrations were similar between the two iceshelf sites $\left(0.149 \mathrm{mg} \mathrm{l}^{-1}\right.$ for MIS and $0.156 \mathrm{mg} \mathrm{l}^{-1}$ for WIS), whereas total phosphorus concentrations were 0.009 and $0.014 \mathrm{mg} \mathrm{l}^{-1}$, respectively. The lowest nutrient concentrations were in Q-Lagoon and WH-Lake, with 0.033 and $0.089 \mathrm{mg} \mathrm{l}^{-1}$ total nitrogen, and 0.004 and $0.003 \mathrm{mgl}^{-1}$ of total phosphorus, respectively.

\section{Pigment diversity}

Each microbial community contained diverse pigments, including chlorophylls, scytonemins, carotenoids and their degradation products (Supplementary Table S3). Chl.- $a$ concentrations ranged from $3.9 \mu \mathrm{g} \mathrm{cm}^{-2}$ (Pond-A) to $42.6 \mu \mathrm{g} \mathrm{cm}^{-2}$ (WIS). Chl.- $b$ was identified in all the sites except WH-Lake, with concentrations of $3.5 \mu \mathrm{g} \mathrm{cm}^{-2}$ or less, whereas chl.-C was only identified in Pond-A $\left(0.5 \mu \mathrm{g} \mathrm{cm}^{-2}\right)$. The cyanobacterial pigment scytonemin and its reduced derivative, red-scytonemin, were the most abundant pigments in mats from WH-Lake, WIS and MIS, with concentrations of up to $474.8 \mu \mathrm{g} \mathrm{cm}^{-2}$ (WIS). Low concentrations of scytonemin were detected in PondA, with $0.28 \mu \mathrm{g} \mathrm{cm}^{-2}$, and none in Q-Lagoon. High concentrations of the carotenoids zeaxanthin, echinenone, $\beta$-carotene and a lutein-like carotenoid were present in all mat samples. The pigments canthaxanthin, fucoxanthin, 19'-hexanoylofucoxanthin and 4ketomyxol-like carotenoid were only separated in some of the microbial mats, with diatoxanthin; astaxanthin and diadinoxanthin-like, antheraxanthinlike, monadoxanthin-like, peridinin-like carotenoids identified only in Pond-A mats.

\section{Morphological classification}

Microscopic analyses confirmed that cyanobacteria constituted the greatest proportion of biomass in all of the High Arctic communities. Based on morphological criteria, they were found to be composed of taxa within orders Chroococcales, Nostocales and Oscillatoriales (Supplementary Table S4). Five known Chroococcales genera were identified (Gloeocapsa cf. alpina, Chroococcus cf. prescotii, Chlorogloea, Aphanocapsa cf. hyalina and Merismopedia cf. angularis), along with one unclassified coccoid morphotype. Genera within order Nostocales included Nostoc, Dichothrix and Tolypothrix, and within the Oscillatoriales the identified genera were Leptolyngbya (Leptolyngbya cf. frigida), Pseudanabaena (Pseudanabaena cf. amphigranulata), Phormidium (Phormidium autumnale) and Oscillatoria (Oscillatoria sancta). Overall we distinguished six Chroococcales, five Nostocales and 13 Oscillatoriales based on classical morphological characters.

\section{Cyanobacterial 16S rRNA gene analysis}

We constructed targeted 16S rRNA gene clone libraries using genomic environmental DNA from 
all the sites, yielding a total of 426 clones with the correct insert. Initial RFLP analysis showed that there were much larger differences among sites than between duplicate samples from the same site (Supplementary Figure S2). The highest diversities were from the three land-based sites, with 12-14 OTUs, defined as $>97.5 \%$ similarity, per site. Similarly, Chao statistics of the land-based sites ranged from 21.7 to 34.7, while the WIS mats contained only five OTUs (Table 1). However, the six cyanobacterial communities did not differ in pairwise comparisons in a weighted Unifrac matrix (Lozupone et al., 2006).

Six OTUs were from order Chroococcales (Figure 1 and Table 2). Three of these were most similar to cultured representatives: clone ArC22 was up to 99.1\% similar to Synechococcus sp. PCC 7502 (AF448080); ArC20 98.5\% to Chamaesiphon subglobosus PCC 7430 (AY170472) and ArC19 98.8\% to Snowella litoralis 1LT47S05, AJ781041). The novel ribotype, ArcC21, had highest similarity of 93.5-93.8\% to Gloeothece sp. SK40 (AB067576). Two other ribotypes had 93.1-93.4\% (ArC23) and 95.8\% (ArC24) similarity to uncultured Gloeobacter sp. HAVOmat17 (EF032784).

Three of the OTUs were within order Nostocales, and one within Stigonematales (Figure 2 and Table 2). Nostocales had the highest sequence similarity to cultured Nostoc spp., including Nostoc commune KU002 (ArcC17, 98.2-98.4\% similarity to AB088375) and Nostoc sp. PCC 7906 (ArcC18, $97.7 \%$ similarity to AB325908), and therefore were conservatively classified as cosmopolitan ribotypes. OTU ArcC16 had less than 94.9\% sequence similarity to Stigonema ocellatum SAG 48.90 (AJ544082) and appears to be a novel phylotype within order Stigonematales.

Fifteen of the OTUs grouped within order Oscillatoriales (Figure 2 and Table 2). Eleven of these had highest similarities $(97.5 \%$ or usually $>99)$ to sequences from cold environments and seven OTUs
(ArcC04-07 and ArcC11-13) were grouped with clones or strains previously identified solely from Antarctic microbial communities, including the Vestfold and Larsemann Hills (East Antarctica), McMurdo Ice Shelf, Lake Fryxell and Lake Bonney (McMurdo Dry Valleys) (Priscu et al., 1998; Taton et al., 2003; Jungblut et al., 2005). At five of the Arctic sites, these clones made up between 20.5 and $70 \%$ of the total diversity (Figure 3 ). The second set of OTUs included ArcC01, 08 and 15, and was grouped with sequences from Antarctic and other cold environments (glaciers and glacial surface snow, Kuytun Glacier 51, Tian Shan Mountains, China; AY493581, AY151728, DQ181742). This set accounted for $12.0-94.4 \%$ of the total diversity. The oscillatorian ribotype ArcC02 shared the highest similarity with an environmental sequence from Kuytun Glacier 51 (surface snow, China; EU263766) and had a relative abundance of $1.3 \%$ in one of the High Arctic sites. All of these three categories of phylotypes were classified as cold ecotypes since they have only been reported from cold habitats to date.

\section{Discussion}

Phototrophic community diversity

Polar cyanobacteria withstand the extremes of their environment through production of photoprotective screening and quenching pigments, as well as by their highly efficient light-capturing systems, nutrient storage ability and freeze-thaw tolerance (Hawes and Schwarz, 2001; Zakhia et al., 2007). The HPLC pigment signatures of the High Arctic assemblages that we sampled in the present study provided semi-quantitative information on phototrophic community composition. Chl.- $a$ concentrations in WH-Lake and WIS were similar to that in earlier reports (Bonilla et al., 2005; Mueller et al., 2005, 2006). Previous studies reported higher concentrations of chl.- $a$ in mats from WIS and MIS than

Table 1 Diversity indices, coverage, number of clones and OTUs for the six microbial mat communities

\begin{tabular}{|c|c|c|c|c|c|c|}
\hline & WH-Lake & A-Pond & Inflow- $A$ & Q-Lagoon & MIS & WIS \\
\hline Number of OTUs & 12 & 14 & 12 & 7 & 10 & 5 \\
\hline Shannon index & 1.6 & 2.0 & 1.8 & 1.3 & 1.8 & 0.7 \\
\hline Chao1 (max.) & 21.7 & 21.7 & 34.7 & ND & 15.3 & ND \\
\hline Coverage & 91.3 & 94.9 & 88 & 98.6 & 98.5 & 98.9 \\
\hline Number of clones & 69 & 78 & 50 & 74 & 66 & 89 \\
\hline \multicolumn{7}{|l|}{ Ribotype assemblage } \\
\hline Antarctic ribotypes (\%) & 40.6 & 20.5 & 70.0 & 62.2 & 51.5 & 4.5 \\
\hline Antarctic and non-polar ribotypes (\%) & 27.5 & 60.3 & 12.0 & 18.9 & 39.4 & 94.4 \\
\hline Non-polar, cold ribotypes (\%) & 0.0 & 1.3 & 0.0 & 0.0 & 0.0 & 0.0 \\
\hline Total cold ecotypes (\%) & 68.1 & 83.3 & 82.0 & 81.1 & 90.9 & 98.9 \\
\hline Non-polar ribotypes (\%) & 2.9 & 11.5 & 10.0 & 18.9 & 9.1 & 1.1 \\
\hline Novel ribotypes (\%) & 29.0 & 6.4 & 8.0 & 0.0 & 0.0 & 0.0 \\
\hline
\end{tabular}

Abbreviations: Inflow-A, inflow from Lake B into Lake A; MIS, Markham Ice Shelf; OUT, Operational Taxonomic Unit; Pond-A, Antoniades Pond; Q-Lagoon, Quttinirpaaq Lagoon; WH-Lake, Ward Hunt Lake; WIS, Ward Hunt Ice Shelf.

ND: Chao1 could not be determined due to low OTU diversity. 


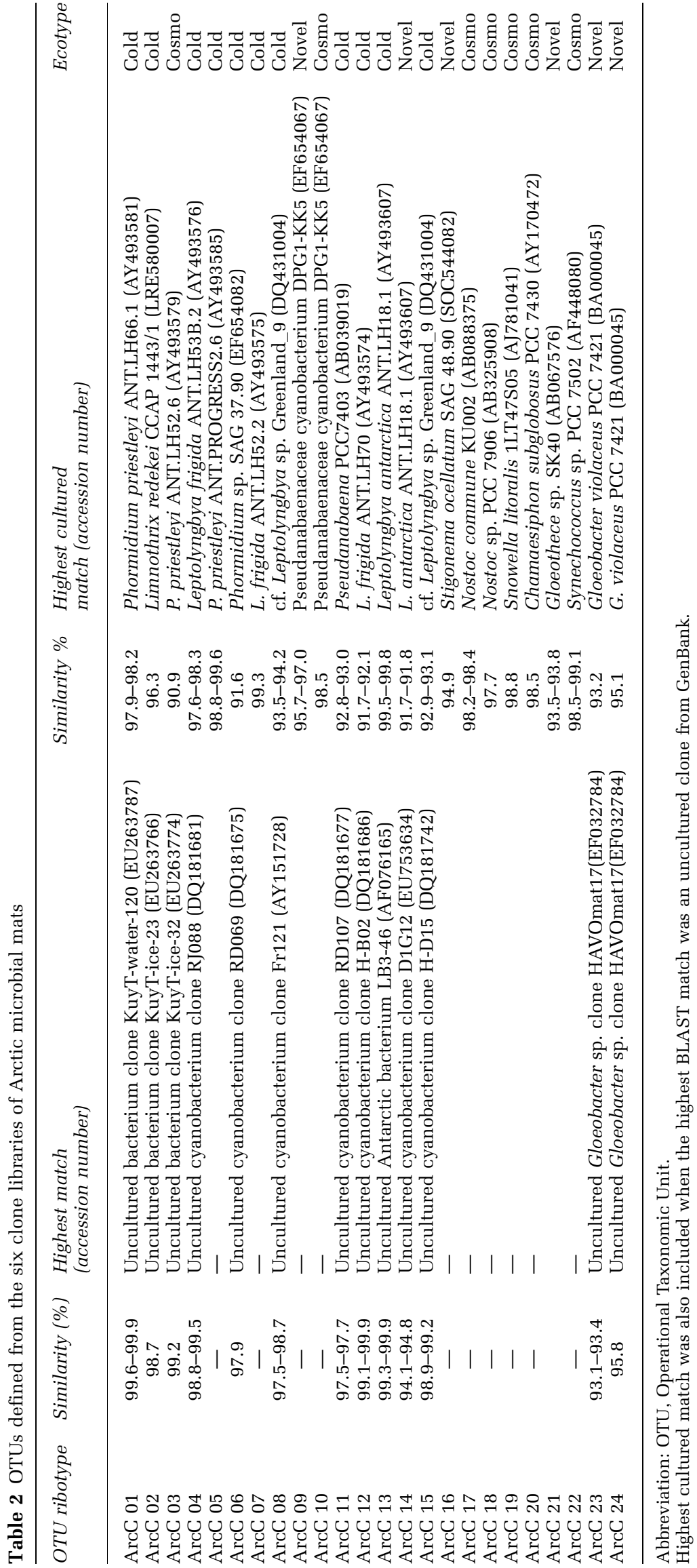




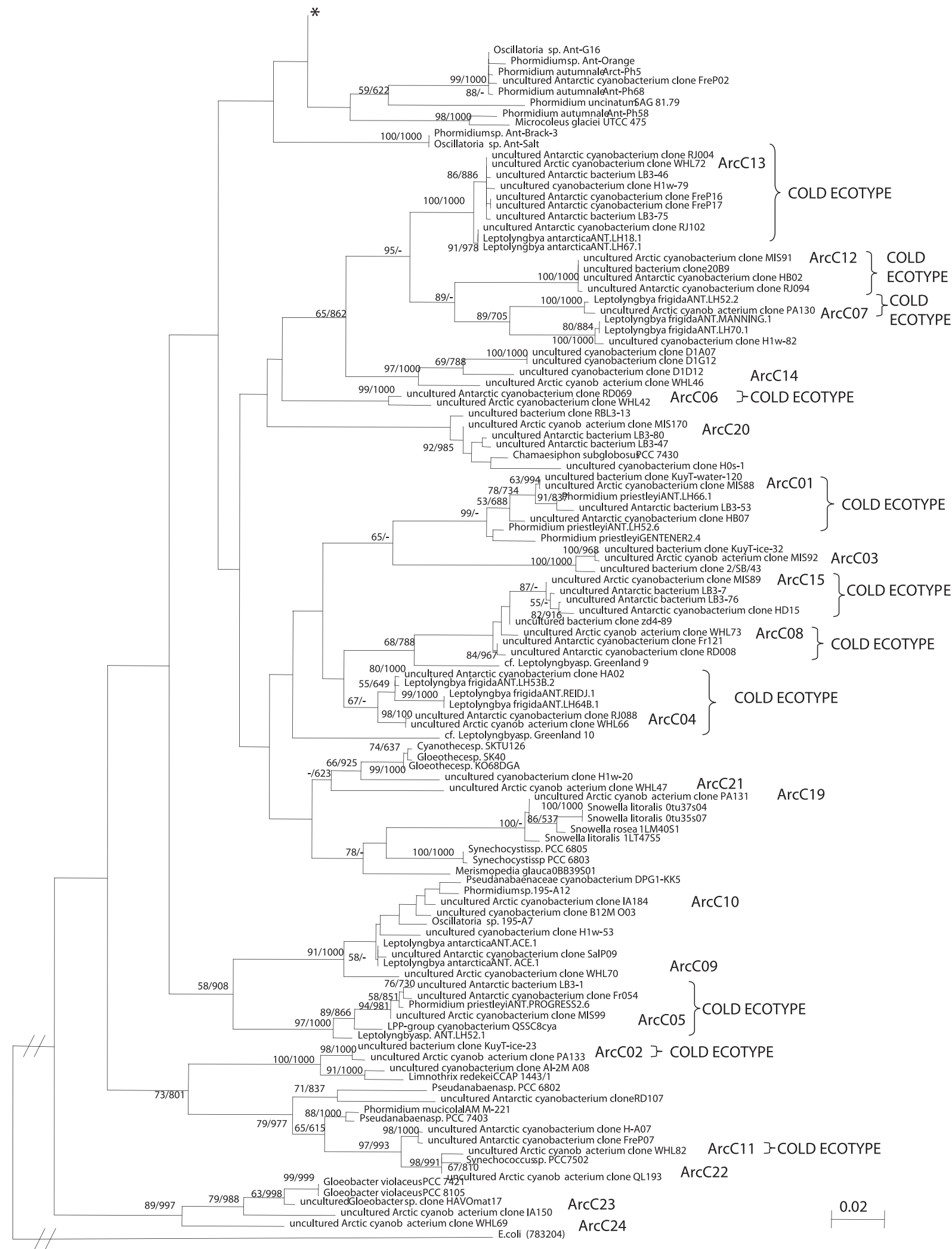




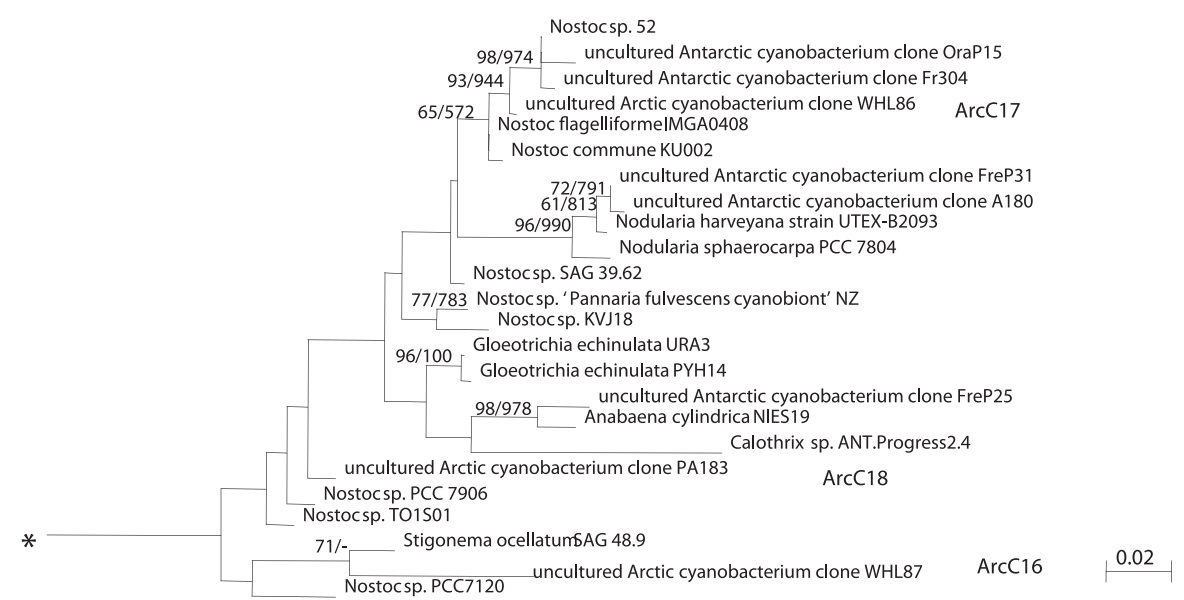

Figure 2 Phylogenetic tree of the identified ribotypes inferred by maximum likelihood within orders Nostocales and Stigonematales from WIS, MIS, Pond-A (PA), Inflow-A (IA), WH-Lake (WHL) and Q-Lagoon (QL) in the High Arctic, based on partial 16S rRNA gene analysis. Bootstrap values based on maximum likelihood (bold) and neighbor-joining methods are indicated at the nodes when equal or greater than 50\%; * indicates where Figure 3 joins this figure. Inflow-A, inflow from Lake B into Lake A; MIS, Markham Ice Shelf; PondA, Antoniades Pond; Q-Lagoon, Quttinirpaaq Lagoon; WH-Lake, Ward Hunt Lake; WIS, Ward Hunt Ice Shelf.

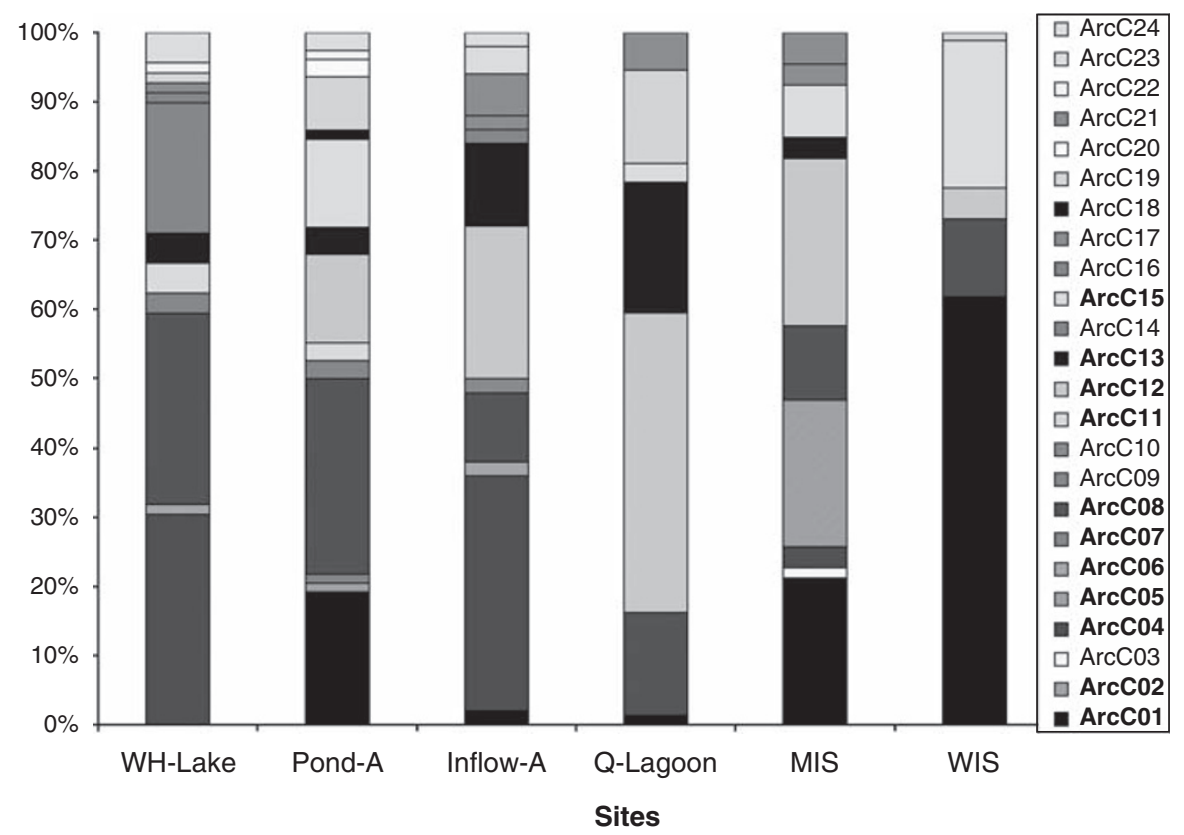

Figure 3 Percentage abundance of ribotypes in the cyanobacterial communities of WH-Lake, Pond-A, Inflow-A, Q-Lagoon, MIS and WIS. Ribotypes are highlighted in bold. Inflow-A, inflow from Lake B into Lake A; MIS, Markham Ice Shelf; Pond-A, Antoniades Pond; Q-Lagoon, Quttinirpaaq Lagoon; WH-Lake, Ward Hunt Lake; WIS, Ward Hunt Ice Shelf.

from Antarctic microbial ice-shelf mats (HowardWilliams et al., 1989, 1990; Mueller et al., 2005). Cyanobacteria-specific markers, such as scytonemin, echinenone, zeaxanthin and canthaxanthin, dominated the microbial mats in WIS, MIS, WHLake and Q-Lagoon, consistent with cyanobacterial dominance of the total phototrophic biomass (Vincent et al., 2004; Bonilla et al., 2005; Mueller et al., 2005), and similar markers have been reported for Antarctic microbial mats (Vincent et al., 1993). In addition, in some of the mats high concentrations of red-scytonemin, a reduced product of scytonemin, were detected; scytonemin and red-scytonemin are sheath pigments, which protect cyanobacterial cells against UV-A radiation.

Chl.- $b$ and lutein, pigments specific to Chlorophyta, were identified in most microbial mats. These pigments could potentially be associated with the genera Mougeotia, Zygnema and Cosmarium, which were identified morphologically in samples 
from WH-Lake by Villeneuve et al. (2001). Similarly the Chlorophytes Chlorosarcinopsis, Chlamydomonas, Chlamydocapsa and Chlorella have been reported previously from WIS (Mueller et al., 2005). In Pond-A, the most abundant and diverse pigments were specific for Chromophyta, including chl.-c2, diadinoxanthin-like, diatoxanthin, astaxanthin, monadoxanthin-like and fucoxanthin. The second highest concentrations of pigments were characteristic for Chlorophyta in Pond-A, and cyanobacteriaspecific signatures were also identified in Pond-A, however at lower concentrations. Diatoxanthin and fucoxanthin are common in diatoms in particular (Jeffrey et al., 1997). Chromophyta-specific pigments were also identified in the other microbial mats, however at lower concentrations. Pond-A temperatures were high compared with that in the other sites, and nutrient concentrations were elevated, potentially due to enrichment by a population of aquatic birds (red-throated loons, Gavia stellata) that we observed at this site.

\section{Morphological diversity}

As in other Arctic and Antarctic freshwater ecosystems, mat-forming cyanobacteria were the most conspicuous members of the well-developed benthic communities. Light-microscopy results were similar to that of previous studies of microbial mat communities from the High Arctic (Bonilla et al., 2005; Mueller et al., 2005). The microbial mat communities were made up of morphospecies within orders Oscillatoriales, Nostocales and Chroococcales, and were similar to Antarctic microbial mats (HowardWilliams et al., 1989; Taton et al., 2003, 2006a,b; Jungblut et al., 2005). Morphospecies in Oscillatoriales were the most abundant taxa at all the sites, followed by those in Chroococcales and Nostocales. In particular, morphospecies related to Leptolyngbya, Pseudanabaena, Phormidium, Oscillatoria and Nostoc are characteristic of polar mats and form their overall structure (Vincent, 2000). The morphological diversity of Chroococcales was similar to freshwater ponds in the Larsemann and Vestfold Hills region; Antarctica, however analogous communities on the McMurdo Ice Shelf and in the McMurdo Dry Valleys, lacked any Chroococcalean morphotypes (Taton et al., 2003; Jungblut et al., 2005).

Interestingly, we did not find Nodularia at any of the Arctic sites, even though it has been described regularly for Antarctic microbial mats, in particular in the McMurdo Ice Shelf, McMurdo Dry Valleys and Larsemann and Vestfold Hills (Taton et al., 2003, 2006a; Jungblut et al., 2005). In contrast, sequences related to Gloeobacter, as found here in the High Arctic, have never been reported from Antarctica. All of these closest matches are to ribotypes from temperate climatic zones, suggesting the connectivity of Arctic environments to lower latitudes. These findings contrast with data on Antarctic mats from the McMurdo Region, which are conspicuously lacking in Chroococcales (Taton et al., 2003; Jungblut et al., 2005).

\section{Biogeography of polar cyanobacteria}

The Polar Regions offer ideal sites for testing microbial endemism since they contain parallel environments separated by vast geographical distances and potential barriers to dispersal (Staley and Gosink, 1999). Many bacteria and microbial eukaryotes have been identified as possibly endemic to Antarctica, including several cyanobacterial species (Komárek, 1999; Taton et al., 2006b). However, our clone-library analyses indicate that three taxa previously identified as Antarctic endemics (Phormidum priestleyi Fritsch, L. frigida (Fritsch) Anagn. and Kom., and Leptolyngbya antarctica (West and West) Anagn. and Kom.; Komárek, 1999; Taton et al., 2006b) were more than 99\% similar to sequences from the Canadian High Arctic (Table 2); for example, ArC05 is $99.6 \%$ similar to $P$. priestleyi (ANT.PROGRESS2.6; AY493585) and ArC13 is $99.8 \%$ similar to $L$. antarctica (ANT.LH18.1; AY493607). Furthermore, several of the uncultured cyanobacterial clones from East Antarctica and the McMurdo Dry Valleys identified as endemic, had the highest percentage match, up to $99.9 \%$, to some of our High Arctic sequences. Similarly, clonelibrary analysis of high-altitude saline wetland mats included a 99\% match to L. frigida (ANT.LH701, AY493574) and L. antarctica (ANT.LH18.1, AY493607) based on partial 16S rRNA gene analyses (Dorador et al., 2008). Nadeau et al. (2001) previously reported that within another clade of Antarctic Oscillatoriales, there was an 11-bp insertion earlier found in a Svalbard soil isolate, which implied a shared evolutionary history.

In sum, these findings suggest the presence of cold-habitat-specific cyanobacterial assemblages, with individual ribotypes that are up to $99.9 \%$ similar in the Arctic and Antarctic, and conspicuously absent from other climate zones. Molecularclock analysis of several bacterial taxa suggests that a $1 \%$ divergence in $16 \mathrm{~S}$ rRNA gene sequence corresponds to an evolutionary time span of approximately 50 million years (Moran et al., 1993; Ochman et al., 1999). This would imply that the Arctic and Antarctic ribotypes described here have been isolated or subject to reduced genetic exchange for less than 10 million years. Cyanobacteria isolated from cold environments all have temperature optima growth rates in the range $15-20^{\circ} \mathrm{C}$, suggesting that they likely had their evolutionary origins within temperate latitudes (Tang et al., 1997; Nadeau et al., 2001) and subsequently colonized perennial cold habitats.

Additional analyses using the ITS region (Comte et al., 2007), multi-locus sequence analyses (Whitaker et al., 2003) and broader genomic and metagenomic analyses are needed to determine whether cold-dwelling oscillatorians belong to 
narrow ecotypes, analogous to the Synechococcus ecotypes from geothermal springs (Bhaya et al., 2007) and N. commune in Antarctica (Novis and Smissen, 2006). An ecotype may be defined as a group of ecologically similar cyanobacteria, with genetic diversity within the ecotype limited by a cohesive force, either periodic selection or genetic drift, or both (Cohan and Perry, 2007), where in our case the environmental force is extreme cold. This corresponds to high-latitude and high-altitude regions where growth of higher plants is severely limited and temperatures are near-zero in summer (Thomas et al., 2008). At least on a 16S rRNA gene level, cyanobacteria from these cold regions are more related to each other than to those in the temperate groups.

Our molecular findings suggest that microbiota of the cryosphere have been globally distributed with local habitat selection (Baas-Becking, 1934; Finlay and Fenchel, 2004). This could occur via mechanisms of long-range transport, similar to atmospheric studies documented for microbes, such as bacteria in Saharan dust transported over the Atlantic (Griffin et al., 2002; Gorbushina et al., 2007), and across Antarctica and the Southern Hemisphere (Hughes et al., 2004; Muñoz et al., 2004). Short-term exchange between the Arctic and Antarctica may be favored by seasonal oscillation of the Hadley cells, which contributes to inter-hemisphere mixing in the troposphere, as revealed by model analysis of long-lived tracers (Bowman and Cohen, 1997).

The present day distribution may be accentuated over longer time scales (Cermeño and Falkowski, 2009) via global freeze-up events such as the Precambrian glaciations (Kirschvink et al., 2000) and dispersal of microbiota throughout the cold biosphere. More recent glacial events may have also favored genetic exchange between the Polar Regions, as suggested for cold-water foraminifers (Darling et al., 2000), although such cooling could also lead to isolation and divergence of some populations (Darling et al., 2004), and dinoflagellates (Montresor et al., 2003).

The dispersal of low-temperature ecotypes may differ from those in other extremes, for example geothermal hot-spring cyanobacteria (Papke et al., 2003; Souza et al., 2008) and hyperthermophiles such as Sulfolobus (Whitaker et al., 2003) that occupy much more localized as well as distantly separated habitats. Furthermore, cold-adapted cyanobacteria are well equipped to withstand potential nutrient limitations, temperature fluctuation, dehydration and elevated UV radiation during longdistance aerial transport. As a result, cold-adapted cyanobacteria may show much reduced genetic divergence in comparison with the known degree of diversification of microbial taxa at the other thermal extreme; for example, Sulfolobus endemism in hot springs (Whitaker et al., 2003). Global circulation models currently predict accelerated warming and massive contraction of glacial environments over the next few hundred years (IPCC, 2007), which may force the cold ecotypes identified here into similarly localized habitats or extinction.

\section{Acknowledgements}

We acknowledge financial support from the Natural Sciences and Engineering Research Council, the Canada Research Chair in Aquatic Ecosystem Studies, the Network of Centres of Excellence program ArcticNet and the International Polar Year Programme MERGE. Logistical support was supplied by the Polar Continental Shelf Project (this is PCSP publication number 04109). Field assistance was provided by Denis Sarrazin, Julie Veillette, Caroline Chénard, Dermot Antoniades, Jérémie Pouliot and Alexandra Pontefract. We also thank the staff of Quttinirpaaq National Park, Parks Canada, for support and facilities, Marie-Josée Martineau for laboratory assistance and four anonymous reviewers for insightful comments and suggestions.

\section{References}

Altschul SF, Gish W, Miller W, Myers EW, Lipman DJ. (1990). Basic local alignment search tool. J Mol Biol 215: 403-410.

Anagnostidis K, Komárek J. (1988). Modern approach to the classification system of cyanophytes: 3-Oscillatoriales. Arch Hydrobiol Suppl 50: 327-472.

Anagnostidis K, Komárek J. (1990). Modern approach to the classification of system of cyanophytes: 5-Stigonematales. Arch Hydrobiol Suppl 86: 1-73.

Baas-Becking LGM. (1934). Geobiologie of inleiding tot de milieukunde. In: van Stockum WP, Zoon NV (eds). The Hague: Netherlands.

Bhaya D, Grossman A, Steunou A-S, Khuri N, Cohan FM, Hamamura $\mathrm{N}$ et al. (2007). Population level functional diversity in a microbial community revealed by comparative genomic and metagenomic analyses. ISME J 1: 703-713.

Bonilla S, Villeneuve V, Vincent WF. (2005). Benthic and planktonic algal communities in a high Arctic lake: pigment structure and contrasting responses to nutrient enrichment. J Phycol 41: 1120-1130.

Bowman KP, Cohen PJ. (1997). Interhemispheric exchange by seasonal modulation of the Hadley circulation. J Atmos Sci 54: 2045-2059.s.

Cermeño P, Falkowski PG. (2009). Controls on diatom biogeography in the ocean. Science 325: 1539-1541.

Cohan FM, Perry E. (2007). A systematics for discovering the fundamental units of bacterial diversity. Curr Biol 17: 373-386.

Comte K, Sabacka M, Carré-Mlouka A, Elster J, Komárek J. (2007). Relationships between the Arctic and the Antarctic cyanobacteria; three Phormidium-like strains evaluated by a polyphasic approach. FEMS Microbiol Ecol 59: 366-376.

Darling KF, Kucera M, Pudsey CJ, Wade CM. (2004). Molecular evidence links cryptic diversification in polar planktonic protists to quaternary climate dynamics. Proc Natl Acad Sci USA 101: 7657-7662. 
Darling KF, Wade CW, Stewart IA, Kroon D, Dingle R, Leigh Brown AJ. (2000). Molecular evidence for genetic mixing of Arctic and Antarctic subpolar populations of planktonic foraminifers. Nature $\mathbf{4 0 5}$ : 43-47.

Dorador C, Vila I, Imhoff JF, Witzel KP. (2008). Cyanobacterial diversity in Salar de Huasco, a high altitude saline wetland in northern Chile: an example of geographical dispersion? FEMS Microbiol Ecol 64: 419-432.

Finlay BJ, Fenchel T. (2004). Cosmopolitan metapopulations of free-living microbial eukaryotes. Protists 155: 237-244.

Felsenstein J. (1989). PHYLIP-phylogeny inference package (version 3.2). Cladistics 5: 164-166.

Garcia-Pichel F, Sherry ND, Castenholz RW. (1992). Evidence for an ultraviolet sunscreen role of the extracellular pigment scytonemin in the terrestrial cyanobacterium Chlorogloeopsis sp. Photochem Photobiol 56: 17-23.

Geitler L. (1932). Cyanophyceae. In: Kolkwitz R (ed). Rabenhorst's Kryptogamenflora von Deutschland, Österreich und der Schweiz. Akademische Verlagsgesellschaft: Leipzig, pp 1-1196.

Gorbushina AA, Kort R, Schulte A, Lazarus D, Schnetger B, Brumsack HJ et al. (2007). Life in Darwin's dust: intercontinental transport and survival of microbes in the nineteenth century. Environ Microbiol 9: 2911-2922.

Griffin DW, Kellogg CA, Garrison VH, Shinn EA. (2002). The global transport of dust. Am Sci 90: 228-235.

Hawes I, Schwarz A-M. (2001). Absorption and utilization of irradiance by cyanobacterial mats in two icecovered Antarctic lakes with contrasting light climates. J Phycol 37: 5-15.

Howard-Williams C, Pridmore R, Downes M, Vincent WF. (1989). Microbial biomass, photosynthesis and chlorophyll a related pigments in the ponds of the McMurdo Ice Shelf, Antarctica. Antarct Sci 1: 125-131.

Howard-Williams C, Pridmore R, Broady P, Vincent WF. (1990). Environmental and biological variability in the McMurdo Ice Shelf ecosystem. In: Kerry K, Hempel G (eds). Antarctic Ecosystems. Ecological Change and Conservation. Springer Verlag: Berlin, pp 23-31.

Hughes KA, McCartney HA, Lachlan-Cope TA, Peace DA. (2004). A preliminary study of airborne microbial biodiversity over Peninsular Antarctica. Cell Mol Biol 50: $537-542$.

Intergovernmental Panel on Climate Change (IPCC), Climate Change (2007). The Physical science basis. In: Solomon et al. (eds). Working Group I Contribution to the Fourth Assessment Report of the IPCC. Cambridge University Press: Cambridge.

Jeffrey SW, Mantoura RFC, Wright SW. (1997). Phytoplankton Pigments in Oceanography. SCOR UNESCO: Paris.

Jungblut AD, Hawes I, Mountfort D, Hitzfeld B, Dietrich DR, Burns BP et al. (2005). Diversity within cyanobacterial mat communities in variable salinity meltwater ponds of McMurdo Ice Shelf, Antarctica. Environ Microbiol 7: 519-529.

Kirschvink JL, Gaidos EJ, Bertani LE, Beukes NJ, Gutzmer J, Maepa LN et al. (2000). Paleoproterozoic snowball earth: extreme climatic and geochemical global change and its biological consequences. Proc Natl Acad Sci USA 97: 1400-1405.
Komárek J. (1999). Diversity of cyanoprokaryotes (cyanobacteria) of King George Island, maritime Antarcticaa survey. Arch Hydrobiol 94: 181-193.

Komárek J, Anagnostidis K. (1989). Modern approach to the classification system of cyanophytes: 4-Nostocales. Arch Hydrobiol Suppl 82: 247-345.

Komárek J, Anagnostidis K. (1998). Cyanoprokaryota 1. Teil Chroococcales. Gustav Fischer Verlag, Jena.

Lozupone C, Hamady M, Knight R. (2006). UniFrac-an online tool for comparing microbial community diversity in a phylogenetic context. BMC Bioinformatics 7: 371-385.

Maidak BL, Cole JR, Lilburn TG, Parker CTJ, Saxman PR, Farris RJ et al. (2001). The RDP-II (Ribosomal Databse Project). Nucleic Acids Res 29: 173-174.

Montresor M, Lovejoy C, Orsini L, Procaccini G, Roy S. (2003). Bipolar distribution of the cyst-forming dinoflagellate Polarella glacialis. Polar Biol 26: 186-194.

Moran NA, Munson MA, Baumann P, Ishikawa H. (1993). A molecular clock in endosymbiotic bacteria is calibrated using the insect hosts. Proc $R$ Soc Lond Ser B 253: 167-171.

Mueller DR, Vincent WF. (2006). Microbial habitat dynamics and ablation control on the Ward Hunt Ice Shelf. Hydrol Proc 20: 857-876.

Mueller DR, Vincent WF, Bonilla S, Laurion I. (2005). Extremotrophs, extremophiles and broadband pigmentation strategies in a high arctic ice shelf ecosystem. FEMS Microbiol Ecol 53: 73-87.

Mueller DR, Vincent WF, Jeffries MO. (2006). Environmental gradients, fragmented habitats, and microbiota of a northern ice shelf cryoecosystem, Ellesmere Island, Canada. Arct Antarct Alp Res 38: 593-607.

Muñoz J, Felicísimo ÁM, Cabezas F, Burgaz AR, Martínez I. (2004). Wind as a long-distance dispersal vehicle in the southern hemisphere. Science 304: 1144-1147.

Nadeau TL, Milbrandt EC, Castenholz RW. (2001). Evolutionary relationships of cultivated Antarctic Oscillatorians (cyanobacteria). J Phycol 37: 650-654.

Novis PM, Smissen RD. (2006). Two genetic and ecological groups of Nostoc commune in Victoria Land, Antarctica, revealed by AFLP analysis. Antarct Sci 18: 573-581.

Ochman H, Elwyn S, Moran NA. (1999). Calibrating bacterial evolution. Proc Natl Acad Sci USA 96: 12638-12643.

Papke RT, Ramsing NB, Bateson MM, Ward DM. (2003). Geographical isolation in hot spring cyanobacteria. Environ Microbiol 5: 650-659.

Priscu JC, Fritsen CH, Adams EE, Giovannoni SJ, Paerl HW, McKay CP et al. (1998). Perennial Antarctic lake ice: an oasis for life in a polar desert. Science $\mathbf{2 8 0}$ : 2095-2098.

Schloss PD, Handelsman J. (2005). Introducing DOTUR, a computer program for defining operational taxonomic units and estimating species richness. Appl Environ Microbiol 71: 1501-1506.

Souza V, Eguiarte LE, Siefert J, Elser JJ. (2008). Microbial endemism: does phosphorus limitation enhance speciation? Nat Rev Microbiol 6: 559-564.

Stackebrandt E, Göbel BM. (1994). A place for DNA-DNA reassociation and 16S rRNA sequence analysis in the present species definition in bacteriology. Int $J$ Syst Bacteriol 44: 846-849.

Staley JT, Gosink JJ. (1999). Poles apart: biodiversity and biogeography of sea ice bacteria. Annu Rev Microbiol 53: $189-215$.

Strainton M, Capel MJ, Armstrong FA. (1977). The Chemical Analysis of Fresh Water (Fish. Mar. Serv. 
Misc. Spec. Publ. 25, 2nd edn.) Canadian Department of Fisheries and Oceans: Winnipeg, Canada.

Tang ET, Tremblay R, Vincent WF. (1997). Cyanobacterial dominance of polar freshwater ecosystems: are highlatitude mat-formers adapted to low temperatures. J Phycol 33: 171-181.

Taton A, Grubisic S, Brambilla E, de Wit R, Wilmotte A. (2003). Cyanobacterial diversity in natural and artificial microbial mats of Lake Fryxell (McMurdo Dry Valleys, Antarctica): a morphological and molecular approach. Appl Environ Microbiol 69: 5157-5169.

Taton A, Grubisic S, Balthazart P, Hodgson DA, LaybournParry J, Wilmotte A. (2006a). Biogeographical distribution and ecological range of benthic cyanobacteria in East Antarctic lakes. FEMS Microbiol Ecol 57: 272-289.

Taton A, Grubisic S, Ertz D, Hodgson DA, Piccardi R, Biondi N et al. (2006b). Polyphasic study of Antarctic cyanobacterial strains. J Phycol 42: 1257-1270.

Taton A, Hoffmann L, Wilmotte A. (2008). Cyanobacteria in microbial mats of Antarctic lakes (East Antarctica)-a microscopical approach. Algological Studies 126: $173-208$.

Thomas DN, Fogg GE, Convey P, Fritsen CH, Gili J-M, Gradinger R et al. (2008). The Biology of the Polar Regions. Oxford University Press: Oxford, pp 394.

Thompson JD, Higgins DG, Gibson TJ. (1994). CLUSTALw; improving the sensitivity of progressive sequence alignment through sequence weighting, position specific gap penalties and weight martix choice. Nucleic Acids Res 22: 4673-4680.

Tillett D, Neilan BA. (2000). Xanthogenate nucleic acid isolation from cultured and environmental cyanobacteria. J Phycol 36: 251-258.
Villeneuve V, Vincent WF, Komárek J. (2001). Community structure and microhabitat characteristics of cyanobacterial mats in an extreme high Arctic environment, Ward Hunt Lake. Nova Hedw 123: 199-224.

Vincent WF. (2000). Cyanobacterial dominance in the Polar Regions. In: Whitton BA, Potts M (eds). The Ecology of Cyanobacteria. Kluwer Academic Publisher: the Netherlands, pp 321-340.

Vincent WF, Downes MT, Castenholz RW, Howard-Wiliams C. (1993). Community structure and pigment organisation of cyanobacteria-dominated microbial mats in Antarctica. Eur $J$ Phycol 28: 213-221.

Vincent WF, Mueller DR, Bonilla S. (2004). Ecosystems on ice: the microbial ecology of Markham Ice Shelf in the high Arctic. Cryobiol 48: 103-122.

Ward DM, Cohan FM, Bhaya D, Heidelberg JF, Kühl M, Grossman A. (2008). Genomics, environmental genomics and the issue of microbial species. Heredity 100: 207-219.

Whitaker RJ, Grogan DW, Taylor JW. (2003). Geographic barriers isolate endemic populations of hyperthermophilic archaea. Science 301: 976-978.

Zakhia F, Jungblut AD, Taton A, Vincent WF, Wilmotte A. (2007). Cyanobacteria in cold environments. In: Margesin R, Schinner F, Marx JC, Gerday C (eds). Psychrophiles: from Biodiversity to Biotechnology. Springer-Verlag: Berlin, pp 121-135.

Zapata M, Rodriguez F, Garrido JL. (2000). Separation of chlorophylls and carotenoids from marine phytoplankton: a new HPLC method using a reversed phase C8 column and pyridine containing mobile phases. Mar Ecol Prog Ser 195: 29-45.

Supplementary Information accompanies the paper on The ISME Journal website (http://www.nature.com/ismej) 